\title{
STOCHASTIC OPTIMAL CONTROL, INTERNATIONAL FINANCE AND DEBT
}

\author{
WENDELL H. FLEMING \\ JEROME L. STEIN
}

CESIFO WORKING PAPER NO. 744

CATEGORY 6: MONETARY POLICY AND INTERNATIONAL FINANCE JUNE 2002 


\title{
STOCHASTIC OPTIMAL CONTROL, INTERNATIONAL FINANCE AND DEBT
}

\begin{abstract}
We use stochastic optimal control-dynamic programming (DP) to derive the optimal foreign debt/net worth, consumption/net worth, current account/net worth, and endogenous growth rate in an open economy. Unlike the literature that uses an Intertemporal Budget Constraint (IBC) or the Maximum Principle, the DP approach does not require perfect foresight or certainty equivalence. Errors of measurement and the effects of unanticipated shocks are corrected in an optimal manner. We contrast the DP and IBC approaches, show how the results of the dynamic programming approach can be interpreted in a traditional simple meanvariance/Tobin-Markowitz context, and explain why our results are generalizations of the Merton model.
\end{abstract}

JEL Classification: C61, D81, D9, F34.

Keywords: stochastic optimal control, foreign debt, international finance, vulnerability to external shocks, sustainable current account deficits.

Wendell Fleming

Division of Applied Mathematics

Brown University

Providence RI 02912

U.S.A.

Wendell_Fleming@Brown.edu
Jerome L. Stein

Division of Applied Mathematics

Brown University

Providence RI 02912

U.S.A.

Jerome_Stein@Brown.edu

Dedicated to the memory of James Tobin (1918 - 2002), teacher and friend. 
7 May 2002

\section{Stochastic Optimal Control, International Finance and Debt Wendell H. Fleming and Jerome L. Stein}

\section{Different Approaches to Intertemporal Optimization in Open Economies}

Optimality conditions provide a benchmark whereby one may evaluate the actual performance of an economy. We would like the optimality conditions to be implementable, in the sense that (a) they involve observable and measurable variables, (b) if followed, would maximize the value of sensible criteria and (c) do not produce very bad results if there is imperfect knowledge or errors of measurement. Our focus is upon an open economy with free movements of capital among countries, where there are debtor and creditor nations. Borrowing abroad to finance capital formation involves two risks. One is the return on domestic investment. The second is the variable interest rate on debt. The variables of interest discussed in this paper are the optimal foreign debt, the current account, the growth rate, and consumption.

(1) The US has been running current account/GDP deficits since 1976, which show no signs of converging to zero. Can one infer that the current account is not optimal? Many people have raised concerns whether such a situation is sustainable. Is the current situation a cause for concern? (2) How should we evaluate whether a foreign debt is "too large" or "unsustainable"? Data on the credit rating of bonds issued in the first half of the 1990s suggest that investors in emerging market securities paid little attention to credit risk, or that they were comfortable with the high level of credit risk that they were incurring ${ }^{1}$. The compression of the interest rate yield spread prior to ${ }^{2}$ and the subsequent turmoil in emerging markets have raised doubts about the ability of investors to 
appropriately assess and price risk. A benchmark is needed to evaluate to what extent a foreign debt deviates from its optimal value.

(3) Countries borrow to finance investment as well as consumption. What is the relation between the optimum foreign debt and the optimal endogenous growth rate of an economy?

Several approaches have been used to derive optimality conditions in open economies. The dominant ones use either "an inter-temporal budget constraint" (IBC) or the Maximum Principle of Pontryagin. It is recognized that these approaches are deficient ${ }^{3}$ in satisfying criteria (a)-(c) above concerning implementability.

As a rule, economists have used the Maximum Principle of Pontryagin to derive optimal control laws. This is an "open loop" type of optimization method that yields an entire sequence of controls to be followed from initial conditions. Half of the initial conditions must be obtained from transversality conditions which imply the solution of differential equations. Given the likelihood of unpredictable disturbances, errors of measurement, formulation and implementation, the overall system will not be stable unless converted into a feedback form. This is to be expected since the optimal path to the desired target is unique. It is clearly advantageous in economics to derive policies in feedback form, where the next move depends upon the current state, since these types of policies are self-correcting and robust to perturbations.

When the economic system is deterministic, the controller can predict the future state of the system knowing the initial conditions and the controls used in the past. In a stochastic system - such as our case where both the productivity of investment and the interest rate are stochastic and hence unpredictable - the controller cannot predict the future, because there are many paths that the system states may follow given the initial conditions and the past controls. Since the controller cannot predict the future, the Dynamic Programming (DP) approach is used, where the optimal controls are based upon the observed state. 
The paper is divided into several parts. In part 2, we describe the endogenous growth model of an open economy subject to productivity and interest rate shocks. This growth model is related to models used in the literature. Box 1 summarizes the basic equations. Part 3 sets up the stochastic optimal control/dynamic programming approach and states the results in Box 2 and as propositions I-V. They provide us with the appropriate benchmarks that satisfy criteria (a)-(c) above.

Our exposition first explains the economic significance and intuition behind our results, and in part 8 we derive them mathematically. Parts 4-7 show that these results have very simple and clear relations to the Mean-Variance approaches developed by James Tobin to whom this paper is dedicated ${ }^{4}$. 'Our work is a generalization of Merton's model of portfolio selection to an open economy. Since both our papers use DP, our results have comparable forms; and both are very different from the literature that uses the IBC or the Maximum Principle. In the subsequent parts, we provide economic explanations of propositions I-V. 


\section{A Continuous Time Infinite Horizon Model}

The endogenous growth model summarized in BOX 1 is a generalization of the models in the literature. There are two sources of uncertainty: the growth rate of GDP, and the interest rate on loans. It is important and realistic to stress that there is a correlation of these two sources of uncertainty, which differs among countries. The model is in real terms and is formulated in terms of the stochastic calculus. To formulate a stochastic control problem associated with the model, we must specify state and control variables, the constraints, the dynamics of the state process and the criterion to be optimized.

There are many criteria of optimality. We use the standard criterion, the maximization over an infinite horizon of the expectation $(E)$ of the discounted $(\delta$ $>0$ ) value of the utility of consumption $\mathrm{U}(\mathrm{C}(\mathrm{t}))$. This is the right hand side of equation (1). The utility function and set $\Gamma$ of constraints and controls are discussed below.

$(1) \mathrm{V}(\mathrm{X})=\max _{\Gamma} \mathrm{E}\left\{\int_{0}^{\infty} \mathrm{U}(\mathrm{C}(\mathrm{t})) \mathrm{e}^{-\delta \mathrm{t}} \mathrm{dt}\right\}$

BOX 1. EQUATIONS OF THE STOCHASTIC GROWTH MODEL

(2) $\mathrm{U}(\mathrm{t})=(1 / \gamma) \mathrm{C}^{\gamma}(\mathrm{t}), \gamma<1 ;(2 \mathrm{a}) \mathrm{U}(\mathrm{t})=\ln \mathrm{C}(\mathrm{t}), \gamma=0$

(3) $\mathrm{C}(\mathrm{t}) \mathrm{dt}=\mathrm{Y}(\mathrm{t}) \mathrm{dt}-\mathrm{r}(\mathrm{t}) \mathrm{L}(\mathrm{t}) \mathrm{dt}-\mathrm{I}(\mathrm{t}) \mathrm{dt}+\mathrm{dL}(\mathrm{t})>0$

(4) $\mathrm{dY}(\mathrm{t}) / \mathrm{Y}(\mathrm{t})=\mathrm{b}(\mathrm{I}(\mathrm{t}) / \mathrm{Y}(\mathrm{t})) \mathrm{dt}+\sigma_{2} \mathrm{dw}_{2} \quad \mathrm{dw}_{2}=\varepsilon_{2} \sqrt{\mathrm{dt}} \quad \varepsilon_{2} \sim \mathrm{N}(0,1)$

(4a) $E[d Y(t) / Y(t)]=b(I(t) / Y(t)) d t$

$(4 b) \operatorname{var}[d Y(t) / Y(t)]=\sigma_{2}^{2} d t$

(5) $d \mathrm{~L}(\mathrm{t})=\mathrm{r}(\mathrm{t}) \mathrm{L}(\mathrm{t}) \mathrm{dt}+[\mathrm{C}(\mathrm{t})+\mathrm{I}(\mathrm{t})-\mathrm{Y}(\mathrm{t})] \mathrm{dt}$

(6) $\mathrm{r}(\mathrm{t}) \mathrm{L}(\mathrm{t}) \mathrm{dt}=\mathrm{rL}(\mathrm{t}) \mathrm{dt}+\sigma_{1} \mathrm{~L}(\mathrm{t}) \mathrm{dw}_{1} ; \mathrm{dw}_{1}=\varepsilon_{1} \sqrt{\mathrm{dt}}_{\mathrm{C}_{1}} \sim \mathrm{N}(0,1)$

(6a) $\mathrm{E}[\mathrm{r}(\mathrm{t}) \mathrm{L}(\mathrm{t}) \mathrm{dt}]=\mathrm{rL}(\mathrm{t}) \mathrm{dt}$;

(6b) $\operatorname{var}[\mathrm{r}(\mathrm{t}) \mathrm{L}(\mathrm{t}) \mathrm{dt}]=\mathrm{E}[\mathrm{r}(\mathrm{t}) \mathrm{L}(\mathrm{t}) \mathrm{dt}-\mathrm{rL}(\mathrm{t}) \mathrm{dt}]^{2}=\mathrm{E}\left[\sigma_{1} \mathrm{~L}(\mathrm{t}) \mathrm{dw}_{1}\right]^{2}=\left(\sigma_{1} \mathrm{~L}(\mathrm{t})\right)^{2} \mathrm{dt}$

(7) $\mathrm{E}\left[\varepsilon_{1} \varepsilon_{2}\right]=\rho, 1 \geq \rho \geq-1$.

(8) $\mathrm{X}(\mathrm{t})=\mathrm{Y}(\mathrm{t}) / \mathrm{b}-\mathrm{L}(\mathrm{t})$ 
$\mathrm{C}(\mathrm{t})=$ consumption, $\mathrm{Y}(\mathrm{t})=\mathrm{GDP}, \mathrm{L}(\mathrm{t})=$ foreign debt, $\mathrm{I}(\mathrm{t})=$ investment, capital $=\mathrm{Y}(\mathrm{t}) / \mathrm{b}$, $\mathrm{r}(\mathrm{t})=$ rate of interest, $\mathrm{X}(\mathrm{t})=$ net worth $=$ capital $-\mathrm{debt}=\mathrm{Y}(\mathrm{t}) / \mathrm{b}-\mathrm{L}(\mathrm{t}) ;$ Brownian motion, $\mathrm{w}_{1}, \mathrm{w}_{2}$.Constraints: $\Gamma=[\mathrm{C}(\mathrm{t})>0, \mathrm{X}(\mathrm{t})>0]$.

Consumption equation (3) is GNP less investment plus net capital inflow, which is current net foreign borrowing. The GNP is the GDP less net interest payments on the foreign debt. The components of BOX 1 are now discussed.

\subsection{Uncertainty concerning the endogenous growth of GDP}

The production function and growth are interrelated. Easterly and Levine (2001) wrote that: "A growing body of research suggests that after accounting for physical and human capital accumulation, 'something else' accounts for the bulk of output growth in most countries." Although physical and human capital accumulation are certainly critical characteristics of the growth process, Easterly and Levine question the historical focus on factor accumulation per se, and upon the traditional smooth Neoclassical production function in capital and labor. The growth $(1 / \mathrm{Y}(\mathrm{t})) \mathrm{dY}(\mathrm{t}) / \mathrm{dt}$ in equation (4) has two components, and does not make a direct recourse to the concept of capital. There are no diminishing returns to investment ${ }^{5}$.

The expected marginal gross return on investment $\mathrm{b}$ is the ratio of the expected growth in output divided by investment/GDP ratio $\mathrm{I}(\mathrm{t}) / \mathrm{Y}(\mathrm{t})$. The endogenous part of growth is equation (4a). Investment per se in either the US or in the EU explains less than $10 \%$ of the growth. The "something else" is contained in the stochastic term. Capital is not directly measurable due to the well known insuperable problems concerning the measurement of technical progress, obsolescence and depreciation. We define "measurable capital" in the sense of Frank Knight. Capital $\mathrm{K}(\mathrm{t})$ is the current GDP capitalized at the stationary gross return $b$ on investment, $K(t)=Y(t) / b$. 
The second element in equation (4) is the stochastic "something else": the product of a standard deviation $\sigma_{2}$ and a Brownian motion term $\mathrm{dw}_{2}=\varepsilon_{2} \sqrt{\mathrm{dt}}$, where $\varepsilon_{2} \sim \mathrm{N}(0,1)$ is a standard normal variable. The stochastic elements are described $^{6}$ in equations $(4 a, 4 b)$. The variance of growth of real GDPis $\sigma_{2}^{2} \mathrm{dt}$. A solution of equation (4) implies the production function ${ }^{7}$.

\subsection{Debt payments uncertainty}

In Fleming and Stein (2001), we considered a discrete time-finite horizon model where borrowing is in the form of short term debt, which must be repaid with interest at maturity ${ }^{8}$. Here, we assume that there is no maturity but the debt must be serviced continually at a variable real interest rate $\mathrm{r}(\mathrm{t})$.

The change in the debt equation (5) is the current account deficit. It is the sum of the interest payments on the debt $\mathrm{L}(\mathrm{t})$ at interest rate $\mathrm{r}(\mathrm{t})$, plus the trade deficit equal to $\mathrm{C}(\mathrm{t})+\mathrm{I}(\mathrm{t})-\mathrm{Y}(\mathrm{t})$ the sum of consumption plus investment less GDP.

The real interest payments $\mathrm{r}(\mathrm{t}) \mathrm{L}(\mathrm{t})$ in equation (5) are stochastic. Equations (6), (6a), (6b) describe the probability distribution function of the stochastic service payments on the debt. The interest costs on the debt $\mathrm{r}(\mathrm{t}) \mathrm{Ldt}$ are distributed normally with a mean of $\mathrm{rL}(\mathrm{t}) \mathrm{dt}$, in equation (6a). The variance is described in (6b) equal to $\mathrm{E}[\mathrm{r}(\mathrm{t}) \mathrm{L}(\mathrm{t}) \mathrm{dt}-\mathrm{rL}(\mathrm{t}) \mathrm{dt}]^{2}=\left(\sigma_{1} \mathrm{~L}(\mathrm{t}) \mathrm{dw}_{1}\right)^{2}=\sigma^{2}{ }_{1} \mathrm{~L}(\mathrm{t})^{2} \mathrm{dt}$. These two moments are implied by equation (6).

2.3 The correlation of the shocks to growth and to the interest rate

Equations $(4 a, 4 b)$ and $(6 a, 6 b)$ describe the uncertainty. The two stochastic terms $d w_{1}, d_{2}$ in equations (4) and (6) are interrelated. The first concerns the variability of the real rate of interest, equation (6b), and the second concerns the variability of the growth of GDP, equation (4b). We consider the general case, equation (7), where the two shocks are not independent: $\mathrm{E}\left(\mathrm{dw}_{1} \mathrm{dw}_{2}\right)=\mathrm{E}\left(\varepsilon_{1} \varepsilon_{2}\right) \mathrm{dt}=$ 
$\rho \mathrm{dt}$. Correlation coefficient $\rho$ could be positive, zero or negative, which varies among countries. There is evidence that: In the advanced countries the correlation $\rho$ is positive. It is negative in the emerging market countries and when there are financial crises in advanced countries.

In the advanced countries such as the USA, the real long term rate of interest $\mathrm{r}(\mathrm{t})$ is positively correlated with growth, due primarily to the business cycle. When investment rises relative to social saving, the economy expands, and there is an excess demand for loans. Real interest rates tend to rise. Over the period 1973:1 - 1997:2 in the US, the correlation coefficient between growth and the real long term interest rate was $\rho=0.24$.

A very different situation exists in the emerging market countries or when there are financial crises in advanced countries ${ }^{9}$. The interaction of the real and financial shocks is described by the correlation coefficient $\rho$. The fragility of the financial system is aggravated by a correlation $\rho<0$, which has been the case in the Emerging Market countries, and in advanced countries during financial crises. The causation between the two shocks $d_{w_{1}}$ and $d_{2}$ runs both ways.

A severe shock to the economy deteriorates the income statements/balance sheets of firms and households. They are unable to repay their debts to the banks. Bank failures rise, lending declines, interest rates on corporate securities rise as credit ratings are downgraded. The financial stringency in turn depresses the economy. Growth declines, but real value of the debt payments $r(t) L(t)$ rises. This negative correlation is extremely important in deriving the optimal debt/net worth ratio for emerging market countries.

Based upon the study by Stein and Paladino, there is a negative relation between growth and the rate of interest on dollar denominated loans $r(t)$ for a panel of emerging market countries 1980 - 2000. In a panel of countries that concluded debt rescheduling agreements on their external private plus public debt 
with commercial banks and with official creditors, the correlation between growth and the interest rate on the external debt $\rho=-0.15$.

\section{The Dynamic Programming Solution}

In this section we state the dynamic programming solution, which is derived in the mathematical section 8 . Then it is given an economic interpretation by showing how it is related to a mean-variance model and is a generalization of the Merton's model.

The state variable is net worth $\mathrm{X}(\mathrm{t})$ defined in equation (8). It is "measurable capital" less foreign debt. Capital is $\mathrm{Y}(\mathrm{t}) / \mathrm{b}$, the present value of the current GDP with a discount rate $b$, which is the mean productivity of investment in equation (4a).

The dynamics of the state variable net worth $\mathrm{X}(\mathrm{t})$ are expressed in equations (9) - (11). The change in net worth $\mathrm{dX}(\mathrm{t})$ is equation (9). (9) $d X(t)=(1 / b) d Y(t)-d L(t)$.

Substitute $d Y(t)$ from equation (4), and the change in the debt from equations (5) and (6) to obtain equation (10).

$(10) d X(t)=[b X(t)+(b-r) L(t))-C(t)] d t-L(t) \sigma_{1} d_{w}+(X(t)+L(t)) \sigma_{2} d_{1} w_{2}$.

The object is to maximize the expected present value of utility equation (1). The choice of utility function is very important. Assume that utility is HARA, equation 2 for $\gamma<1$, or equation $2 \mathrm{a}$ when $\gamma=0$. Equation (1) becomes equation (1a).

$$
(1 \mathrm{a}) \mathrm{V}(\mathrm{X})=\max _{\Gamma} \mathrm{E}\left\{\int_{0}^{\infty}(1 / \gamma) \mathrm{C}(\mathrm{t})^{\gamma} \mathrm{e}^{-\delta \mathrm{t}} \mathrm{dt}\right\}, \gamma<1 \text {. }
$$

There are several advantages to the use of the HARA function. First: it reduces the dimension of the problem and allows us to solve the model analytically. Second; it is scale independent. It is valid regardless of the size of the economy. Mathematically this is expressed by the property $\mathrm{V}(\mathrm{X})=(1 / \gamma) \mathrm{AX}^{\gamma}$ for a 
suitable constant $\mathrm{A}>0$. The constant $\mathrm{A}$ is determined by formula (11). Risk aversion requires that $\gamma<1$. If we assume that $\gamma \leq 0$, we do not have to make any restrictions on the discount factor $\delta$, which would be needed if we only assumed ${ }^{10}$ that $\gamma<1$. Consumption $\mathrm{C}(\mathrm{t})$ is described by equation (3). Our benchmark system, with net worth $\mathrm{X}(\mathrm{t})>0$, is constrained to preclude Ponzi schemes. The HARA utility function allows us to use as controls the $\underline{\text { ratios }}$ of: debt/net worth $\mathrm{f}=\mathrm{L} / \mathrm{X}=$ $\mathrm{k}-1=\mathrm{capital} /$ net worth $\mathrm{k}$ minus 1 , and consumption/net worth $\mathrm{c}=\mathrm{C} / \mathrm{X}$. Equation (10a) is in terms of the control ratios f and $\mathrm{c}$.

$(10 a) d X(t)=[(b-c)+(b-r) f] X(t) d t-f X(t) \sigma_{1} d w_{1}+(1+f) X(t) \sigma_{2} d w_{2}$.

The optimization (1a) is subject to the dynamic equation (10a) and to the constraints $\mathrm{C}(\mathrm{t})>0, \mathrm{X}(\mathrm{t})>0$.

The control variables are consumption ratio $\mathrm{c}(\mathrm{t})$ and the debt ratio $\mathrm{f}(\mathrm{t})$. Given the nature of the uncertainty, the controller cannot anticipate the future. This is fundamentally different from the "forward looking/ certainty equivalent" models in the economics literature ${ }^{11}$, but it is the same orientation as the Merton approach in mathematical finance. The admissible controls are chosen using any information known up to time t. We therefore consider the controls which enter as feedback functions of the state $\mathrm{X}(\mathrm{t})$. A simplifying assumption is that the controls $\mathrm{c}(\mathrm{t}), \mathrm{f}(\mathrm{t})$ can be varied instantaneously and costlessly.

The dynamic programming equations for the optimal ratio of debt/net worth $\mathrm{f}^{*}$ and consumption/net worth $\mathrm{c}^{*}$ are derived from equation (11). This equation is derived in part 8. Parts 4-7 provide clear and economically significant and sensible implications of equation 11.

DYNAMIC PROGRAMMING MAXIMIZATION

$$
\begin{gathered}
\text { (11) } \delta / \gamma=\max _{\mathrm{c}}\left[(1 / \gamma) \mathrm{c}^{\gamma} / \mathrm{A}+(\mathrm{b}-\mathrm{c})\right]+\max _{\mathrm{f}}\left\{[(\mathrm{b}-\mathrm{r}) \mathrm{f}]-(1-\gamma) \sigma_{2}{ }^{2} / 2\left[\left(\mathrm{f}^{2} \theta^{2}\right)\right.\right. \\
\left.\left.+(1+\mathrm{f})^{2}-2(1+\mathrm{f}) \mathrm{f} \rho \theta\right]\right\}
\end{gathered}
$$

In particular, this equation is at the core of the Mean-Variance analysis, to be discussed below. We focus upon four crucial variables: optimal foreign debt/net 
worth (part 4), a negative foreign debt is a positive foreign asset; the optimal expected endogenous growth rate and optimal consumption/net worth (part 6), and optimal current account/net worth (part 7). Propositions I-V summarize our contribution to the literature. Net worth $\mathrm{X}(\mathrm{t})$ equals capital less debt. Since capital/net worth less debt/net worth equals one, the propositions apply to the optimal ratio k* of "capital"/net worth. BOX 2 states the implications of DP equation (11) for the optimal debt/net worth, capital/net worth and consumption/net worth. The economic interpretation is in sections $4-7$.

PROPOSITION I. The optimal debt/net worth $\mathrm{f}^{*}$ and capital/net worth $\mathrm{k}^{*}$ maximize a mean-variance function of expected return and risk.

PROPOSITION II. The optimal $\mathrm{f}^{*}$ or $\mathrm{k}^{*}=1+\mathrm{f}^{*}$ are independent of the optimal ratio of consumption/net worth.

PROPOSITION III. The optimal debt/net worth $\mathrm{f}^{*}$ or capital/net worth $\mathrm{k}^{*}$ maximize the expected endogenous growth rate, for any constant consumption ratio.

PROPOSITION IV. The optimal debt/net worth will only be positive if the expected return exceeds the expected real interest rate by an amount that depends upon the correlation of the growth and interest rate risks and their variances. PROPOSITION V. The optimal expected current account deficit/net worth is a quadratic function of the optimal debt/net worth. Permanent current account deficits/net worth are optimal if $\mathrm{f}^{*}$ and expected growth are positive.

Proposition II is seen directly from an inspection of equation (11). The maximization with respect to the debt/net worth is independent of the maximization with respect to consumption/net worth ${ }^{12}$. Equation (12) for the optimal debt/net worth illustrates the strengths of the DP approach. In the model, the expected return on investment $b$ in equation (4) is a constant: there are no diminishing returns. Similarly, the expectation of the real interest rate $r$ in equation (6) is constant. Assume that $b>r$, as is the case in the $\mathrm{US}^{13}$. In the conventional approach, the optimal stock of capital is such that the expected 
return is equal to the interest rate. Since $b>r$, the country should increase its capital without limit. Insofar as the saving ratio is given, the foreign debt should rise without limit.

\footnotetext{
BOX 2 SUMMARY OF OPTIMAL (*) CONTROLS debt/net worth

(12) $\mathrm{f}^{*}=(\mathrm{b}-\mathrm{r}) /(1-\gamma) \sigma^{2}+\lambda(\rho \theta-1)=(\mathrm{b}-\mathrm{r}) /(1-\gamma) \sigma^{2}+\mathrm{f}(0)$.

"capital"/net worth

(13) $[(\mathrm{Y}(\mathrm{t}) / \mathrm{b}) / \mathrm{X}(\mathrm{t})]^{*}=\mathrm{k}^{*}=1+\mathrm{f}^{*} \geq 0$,

consumption/net worth

(14) $\mathrm{c}^{*}=\mathrm{C}(\mathrm{t}) / \mathrm{X}(\mathrm{t})=\mathrm{A}^{-1 /(1-\gamma)} ; \mathrm{c} *=\delta$, when $\gamma=0$.

Symbols: Net worth $\mathrm{X}(\mathrm{t})=\mathrm{Y}(\mathrm{t}) / \mathrm{b}-\mathrm{L}(\mathrm{t})$; Expected net return $=(\mathrm{b}-\mathrm{r})$; Total risk $=\sigma^{2}=\operatorname{var}(\mathrm{dY}(\mathrm{t}) / \mathrm{Y}(\mathrm{t})-\mathrm{r}(\mathrm{t}))=\left(\sigma_{1}{ }^{2}+\sigma_{2}{ }^{2}-2 \rho \sigma_{1} \sigma_{2}\right)>0 ; \theta=\sigma_{1} / \sigma_{2}=$ standard deviation of interest rate/ standard deviation of growth; $\rho=$ correlation between interest rate and growth; $\lambda=\left(\sigma_{2}{ }^{2} / \sigma^{2}\right)=1 /\left(1+\theta^{2}-2 \rho \theta\right)>0$.Intercept term $f(0)$. $=\lambda(\rho \theta-1)$
}

The DP approach yields a different result. Equation (12), graphed in figure 1 as curve U-S, relates the ratio $\mathrm{f}^{*}$ of the optimal debt/net worth to the expected net return on investment $(b-r)$. The ratio of "capital"/net worth $k^{*}=1+f^{*}$, so that the graph can be used to determine either debt or capital relative to net worth. In the $M-V$ section 4, we explain in detail how this equation and the optimal growth equation can be understood in a Mean-Variance framework. 


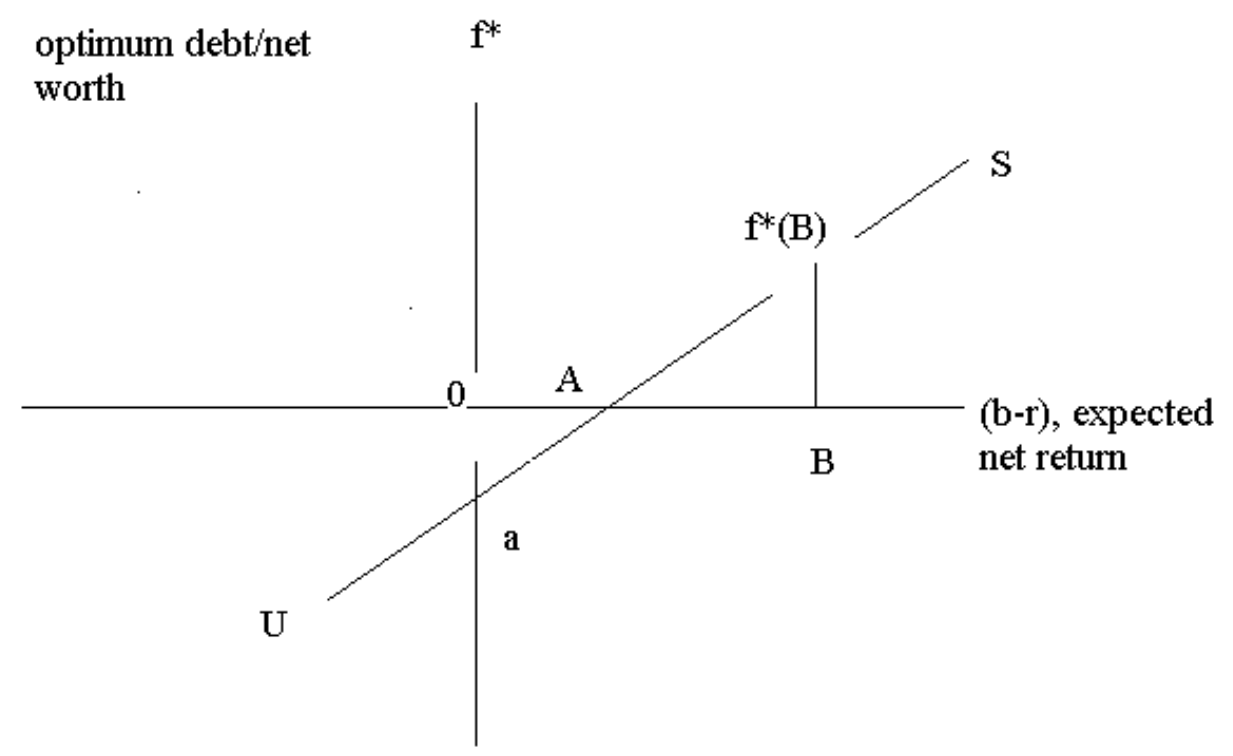

Optimal debt/net worth $=$ optimal capital/net worth $-1 \quad f(0)=0 \mathrm{a}$, minimum risk point.

The slope of the curve $1 /(1-\gamma) \sigma^{2}$ is the reciprocal of "total risk" times risk aversion. Total risk $\sigma^{2}$ is the variance of the net return $=\operatorname{var}(d Y(t) / Y(t)-r(t))=$ $\left(\sigma_{1}^{2}+\sigma_{2}^{2}-2 \rho \sigma_{1} \sigma_{2}\right)>0$. The intercept $f(0)=\lambda(\rho \theta-1)$ is the optimal ratio 
debt/net worth when the expected net return is zero. It can be positive, zero or negative. In the section 8 , we show that $\mathrm{f}(0)$ is the ratio of debt/net worth that minimizes total risk. Based upon estimates for the US ${ }^{14}$, we draw curve U-S in figure 1. The intercept $f(0)$ is negative because $\rho \theta=(0.26)(0.18)<1$, the correlation $\rho=0.26$ between the two risks is not sufficiently high ${ }^{15}$. At the minimum risk point, the US should be a creditor. The term $\lambda=\left(\sigma_{2}{ }^{2} / \sigma^{2}\right)$ is about 1.05 in the US. The risk associated with the gross return on investment var $(b)=$

$\sigma_{2}^{2}$ is about $5 \%$ greater than the total risk associated with the net return on investment var $(b-r)=\sigma^{2}$ in the US.

Equation (12)/ figure 1 states that, as long as the expected net return is less than $0 \mathrm{~A}=\sigma_{2}^{2}(1-\gamma)(1-\rho \theta)$, the ratio of debt/net worth should be negative: the country should be a creditor. As the expected net return rises above $0 \mathrm{~A}$, the country should finance capital with debt. At expected net return $0 \mathrm{~B}$, the ratio of optimal debt/net worth is $\mathrm{f}^{*}(\mathrm{~B})$ and optimal capital/net worth is $1+\mathrm{f}^{*}(\mathrm{~B})$, both are finite. A debt/net worth is excessive/non-optimal, insofar as it lies above a line such as U-S in figure 1 . If the expected net return $(b-r)=0 B>0$, the conventional literature would imply that an unlimited amount of debt should be incurred. We have shown that the DP result equation (12) is quite different from that derived in the conventional literature, when there is imperfect knowledge of a deterministic system $^{16}$ or the system is stochastic.

\section{A "mean-variance" (M-V) interpretation}

The Tobin ${ }^{17}$ mean variance $(\mathrm{M}-\mathrm{V})$ analysis is the cornerstone of much of the work in the field of investment/portfolio allocation analysis. It is based upon a two period model of portfolio choice between "safe" and "risky" assets, and yields clear and operational results. Our model in BOX 1 seems to be quite different. There is an infinite horizon; there is risk on both the debt and on capital. A negative debt is a positive holding of financial assets. Growth is endogenous. We 
show ${ }^{18}$ how the DP equations in BOX 2 can be related to the M-V analysis. This is the subject of this section.

The optimal values of debt/net worth $\mathrm{f}^{*}$ or "capital"/net worth $\mathrm{k}^{*}=1+\mathrm{f}^{*}$ maximize the value function equation $\mathrm{V}(\mathrm{X})$ in (1) subject to the law of motion of the state variable $X(t)$ net worth, equation (10a). In the M-V analysis, the object is to select a portfolio of risky and safe assets to maximize a $V^{*}=M-(1-\gamma) R$, a linear combination of a mean $\mathrm{M}$ and $(1-\gamma) \mathrm{R}$ a risk R times risk aversion $(1-\gamma)>0$. To relate the DP equation (12) for the optimal debt to the maximization of $\mathrm{V}^{*}$ in the $\mathrm{M}-\mathrm{V}$ analysis we must have expressions for "mean" $\mathrm{M}$ and "risk" $\mathrm{R}$, which are based upon the model in BOX 1.

In general, for all positive risk aversion, the optimal consumption $\mathrm{C}(\mathrm{t})$ will be a constant $\mathrm{c} *$ times net worth $\mathrm{X}(\mathrm{t})$. Therefore, the growth of consumption will equal the growth in net worth ${ }^{19}$, equation (15). (15) $(1 / \mathrm{t}) \ln [\mathrm{C}(\mathrm{t}) / \mathrm{C}(0)]=(1 / \mathrm{t}) \ln [\mathrm{X}(\mathrm{t}) / \mathrm{X}(0)]=$ growth rate Equation (16), "expected growth", is derived from the solution of stochastic differential equation (10a). If one starts from equation (16), we show how the dynamic programming results summarized in $B O X 2$ can be given an interpretation in the traditional "mean-variance" portfolio choice model.

Expected growth of consumption and net worth (16) $(1 / \mathrm{t}) \mathrm{E}[\ln \mathrm{C}(\mathrm{t}) / \mathrm{C}(0)]=(1 / \mathrm{t}) \mathrm{E}[\ln \mathrm{X}(\mathrm{t}) / \mathrm{X}(0)]$

$$
\begin{aligned}
& =[(b-c)+(b-r) f]-\left(\sigma_{2}^{2} / 2\right)\left[f^{2} \theta^{2}+(1+f)^{2}-2 f(1+f) \rho \theta\right] \\
& =M(f, c)-R(f)
\end{aligned}
$$

Divide equation (16) into two parts, which correspond to Mean and Risk. They are defined below in equations (17) and (18) respectively. In the discussion here, the ratios $\mathrm{f}$ and $\mathrm{c}$ are assumed constant. The mean return $\mathrm{M}$ is expected growth if there were no risks. It is independent of the variances and covariances.

(17) $\mathrm{M}=[(\mathrm{b}-\mathrm{c})+(\mathrm{b}-\mathrm{r}) \mathrm{f}]$ 
The mean return $\mathrm{M}$ depends upon: $(\mathrm{b}-\mathrm{c})$ the expected return on investment less the ratio of consumption/net worth, plus the expected rate of return less the real interest rate (b-r) times $\mathrm{f}$ the ratio of debt/net worth.

The variance of the growth rate var $\{1 / \mathrm{t}) \ln [\mathrm{X}(\mathrm{t}) / \mathrm{X}(0)]\}$ is equation $(18 \mathrm{a})$, which is independent of the consumption ratio and depends upon one control variable, the debt/net worth.

Variance of consumption and growth

$$
\begin{aligned}
& (1 / t) \operatorname{var}[\ln \mathrm{C}(\mathrm{t}) / \mathrm{C}(0)]=(1 / \mathrm{t}) \operatorname{var}[\ln \mathrm{X}(\mathrm{t}) / \mathrm{X}(0)] \\
& =\left[\mathrm{f}^{2} \sigma_{1}{ }^{2}+(1+\mathrm{f})^{2} \sigma_{2}{ }^{2}-2 \mathrm{f}(1+\mathrm{f}) \rho \sigma_{1} \sigma_{2}\right]=\sigma_{2}{ }^{2}\left[\mathrm{f}^{2} \theta^{2}+(1+\mathrm{f})^{2}-2 \mathrm{f}(1+\mathrm{f}) \rho \theta\right]
\end{aligned}
$$

Define Risk R, equation (18), as equal to one half of the variance of growth. Risk $\mathrm{R}$ only contains variances, covariances and debt/net worth. The variance of the return is $\sigma_{2}{ }^{2}$, the variance of the interest rate is $\sigma_{1}{ }^{2}$, the ratio $\theta=\sigma_{1} / \sigma_{2}$ and $\rho$ is the correlation between the disturbances.

(18) $\mathrm{R}=\left(\sigma_{2}^{2} / 2\right)\left[\mathrm{f}^{2} \theta^{2}+(1+\mathrm{f})^{2}-2 \mathrm{f}(1+\mathrm{f}) \rho \theta\right]$

Define Expected $M-V$ utility as $\mathrm{V}^{*}$ in equation (19): the Mean less the product of risk aversion $(1-\gamma)>0$ and Risk.

(19) $V^{*}(f, c)=M(f, c)-(1-\gamma) R(f)$

There is a correspondence between the DP solution, based upon stochastic optimal control equation (11), and the M-V approach equation (19), because DP equation (11) can be written as equation (20) using the definitions for "mean" M and risk "R" above. Equation (20) shows that the maximization with respect to the optimal debt/net worth is the same in either approach. Recall that a negative debt is a positive financial asset position.

(20) $\delta / \gamma=\max _{\mathrm{c}, \mathrm{f}}\left\{(1 / \gamma) \mathrm{c}^{\gamma} / \mathrm{A}+\mathrm{M}(\mathrm{f}, \mathrm{c})-(1-\gamma) \mathrm{R}(\mathrm{f})\right\}=\max \left\{(1 / \gamma) \mathrm{c}^{\gamma} / \mathrm{A}+\mathrm{V}^{*}(\mathrm{f}, \mathrm{c})\right\}$

A graphic discussion of the correspondence between the two approaches, for the optimum debt/net worth, is the subject of the next section. 


\section{Optimal ratio of foreign debt/net worth: Mean-Variance and a Generalization of Merton solution}

A M-V interpretation of equation (12) for the optimal debt/net worth is done graphically in this section. Suppose that we select a debt/net worth ratio that maximizes the "mean-variance expected utility" $V^{*}=M(f, c)-(1-\gamma) R(f)$ equation (19).

The mean $M(f, c)$ in (17) is a linear function of $f$ the debt/net worth. The slope of the Mean function is $\mathrm{M}_{\mathrm{f}}=(\mathrm{b}-\mathrm{r})$, the expected return less the expected interest rate, is independent of the debt and consumption. There are no diminishing returns to investment. Intercept (b-c) is the expected return less the consumption ratio. Variations in the consumption ratio only affect the intercept and not the slope of the Mean function.

Risk R(f) in (18) is a quadratic function of the debt/net worth, which is independent of consumption and the net return. Total risk $R(f)$ is not the same as the variance of the return on investment $\sigma_{2}{ }^{2}$. Borrowing to finance real investment involves a risky return and a risky interest rate liability The two risks may be correlated positively or negatively, or may be independent of each other. The uncertainty concerns the variance of the net return.

Quadratic risk function ${ }^{20} R(f)$ reaches a minimum at $f(0)$ in figure 2 and rises as the net debt/net worth deviates from $\mathrm{f}(0)$. The minimum ${ }^{21}$ risk ratio of $\mathrm{debt} /$ net worth at $\mathrm{f}(0)=(\rho \theta-1) /\left(1+\theta^{2}-2 \rho \theta\right)$, is the intercept term in equation (12) and figure 1 . To minimize risk, the country should be a debtor (creditor) if quantity $(\rho \theta-1)$ is positive (negative).

The mean-variance interpretation of the DP equation (11) is that the optimal ratio $\mathrm{f}^{*}$ of debt/net worth in figure 2 maximizes expected $\mathrm{M}-\mathrm{V}$ utility $\mathrm{V}^{*}$ equal to the difference between mean return and risk times risk aversion. $\mathrm{f}^{*}=\operatorname{argmax}\left[\mathrm{V}^{*}=\mathrm{M}(\mathrm{f}, \mathrm{c})-(1-\gamma) \mathrm{R}(\mathrm{f})\right]$ 
This optimal ratio is precisely the $f^{*}$ in equation (12), derived from the DP solution of the stochastic optimal control/ infinite horizon model.

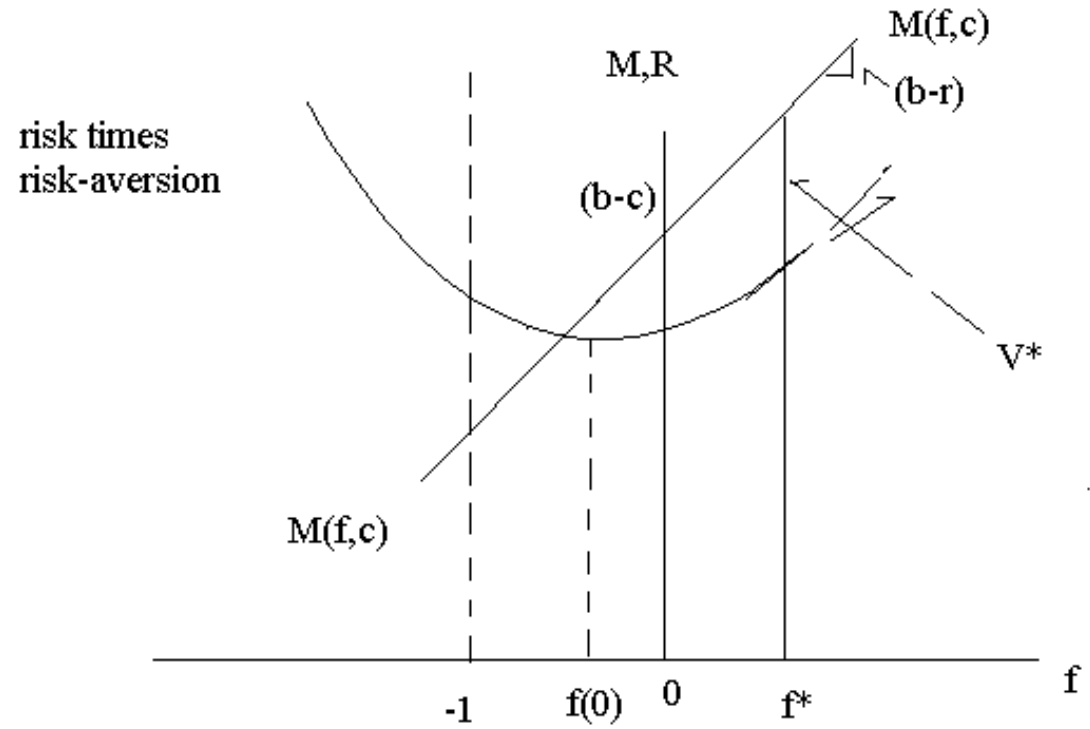

$\mathrm{M}-\mathrm{V}$ mean variance interpretation of DP equation (12) for optimal debt/net worth, expected growth rate. Optimal debt/net worth $\mathrm{f}^{*}$ same as equation (12). 
The optimal ratio of "capital"/net worth is $\mathrm{k}^{*}=1+\mathrm{f}^{*}$; therefore, we could have used the maximization with respect to $\mathrm{k}$ instead of with $\mathrm{f}$. Our approach is a generalization of the Merton model to an open economy with two types of risk. In Merton's model ${ }^{22}$, the investor has wealth $\mathrm{X}(\mathrm{t})$ which he divides between a risky asset and a safe asset. The price of the risky asset follows a Brownian motion process similar to our equation (4), and there is no interest rate risk $\sigma_{1}=0$. The well-known Merton equation (1990:111) for the ratio of risky assets/net worth $\mathrm{k}^{*}$ is a special case of our equation (12). Since there is no interest rate risk: $\theta=0, \rho=$ $0, \lambda=1$. The resulting ratio of risky assets/net worth, $\mathrm{k}^{*}=1+\mathrm{f}^{*}=(\mathrm{b}-$ $\mathrm{r}) /(1-\gamma) \sigma_{2}{ }^{2}$, is the well-known Merton solution. We have shown that our DP approach generalizes the Merton model. Since we both use dynamic programming, we both obtain results very different from the open economy models, which use either the intertemporal budget constraint or the Maximum Principle.

\section{Optimum Consumption and Growth}

The DP equation (11) implies equations for optimal consumption and, with (10a), endogenous growth. The implications are quite different from that derived from the Inter-temporal budget constraint (IBC) literature. Expected growth g, the M-V expected utility $\mathrm{V}^{*}$ and the DP equation are intimately related, as can be seen from equations (16),(19) and (20.

(20) $\delta / \gamma=\max _{\mathrm{c}, \mathrm{f}}\left\{(1 / \gamma) \mathrm{c}^{\gamma} / \mathrm{A}+\mathrm{M}(\mathrm{f}, \mathrm{c})-(1-\gamma) \mathrm{R}(\mathrm{f})\right\}=\max \left\{(1 / \gamma) \mathrm{c}^{\gamma} / \mathrm{A}+\mathrm{V}^{*}(\mathrm{f}, \mathrm{c})\right\}$,

\section{[DP]}

(16) $g=(1 / t) E[\ln X(t) / X(0)]=M(f, c)-R(f)$

(19) $V^{*}(f, c)=[M(f, c)-(1-\gamma) R(f)]$,

[M-V]

There are several points of note. First: if risk aversion $(1-\gamma)=1$, then expected growth $\mathrm{g}$ in equation (16) is the same as expected $\mathrm{M}-\mathrm{V}$ utility $\mathrm{V}^{*}$ in (19). The difference between the straight line $M(f, c)$ and the risk curve $R(f)$ is 
expected M-V utility equal to expected growth g. Second: as we have seen, for example in (11) and figure 2, the optimal ratio $\mathrm{f}^{*}$ of debt/net worth is independent of the consumption ratio $\mathrm{c}$. Variations in the consumption ratio change the intercept, but not the slope, of the line $M(f, c)$, and do not affect the curve for risk $\mathrm{R}(\mathrm{f})$. Third: decreases in the consumption ratio increase $\mathrm{M}-\mathrm{V}$ utility and the expected growth rate in equation (16) by shifting the mean line $M(f, c)$ upwards. However, from DP equation (20), the optimal consumption ratio must also take into account current consumption - the first term - and not just M-V expected utility $\mathrm{V}^{*}$.

As proved in the mathematical part below, optimal consumption/net worth $c^{*}$ is a constant. If the utility function is logarithmic, risk aversion $(1-\gamma)=1$, then the optimal ratio of consumption/net worth is equal to the discount rate $\delta$ in equation (21). The ratio of optimal consumption/GDP, $\mathrm{C}(\mathrm{t}) / \mathrm{Y}(\mathrm{t})=\mathrm{c} *(\mathrm{y})$ is equation (22), where the optimal debt/net worth $\mathrm{f}^{*}$ is given by equation (12). (21) $\mathrm{c}^{*}=\mathrm{C}(\mathrm{t}) / \mathrm{X}(\mathrm{t})=\delta$ $(22) \mathrm{c}^{*}(\mathrm{y})=\mathrm{C}(\mathrm{t}) / \mathrm{Y}(\mathrm{t})=\delta\left[(1 / \mathrm{b})-\mathrm{f}^{*}\right]=\delta\left[(1 / \mathrm{b})-\lambda(\rho \theta-1)-(\mathrm{b}-\mathrm{r}) / \sigma^{2}\right]$

The equation for optimal consumption/GDP derived from DP, in either our model or Merton's, is quite different from that contained in the IBC literature. There is no use of the concept of the expected present value of future income, since that concept is unknowable and clearly not objectively measurable. In our case, optimal consumption/GDP is negatively related to the expected return on investment $\mathrm{b}$ and to the optimal debt/net worth $\mathrm{f}^{*}$. When the utility function is logarithmic, then the factor of proportionality is the discount rate ${ }^{23}$.

Knowing optimal consumption $\mathrm{c}^{*}$ from (21), we know the intercept of the line $M(f, c)$ in figure 2 . The optimal debt/net worth $\mathrm{f}^{*}$ is derived for any consumption ratio. Therefore, the optimal endogenous growth $\mathrm{g}^{*}$ is equation (23), when $(1-\gamma)=1$. It is the difference between the $M(f, c)$ line and $R(f)$ curve, 
evaluated at $\mathrm{c}^{*}, \mathrm{f}^{*}$ from equation (21) and (12) respectively. (23) $\mathrm{g}^{*}=\mathrm{M}\left(\mathrm{f}^{*}, \mathrm{c}^{*}\right)-\mathrm{R}\left(\mathrm{f}^{*}\right)$.

\section{Optimum Current Account}

It is frequently argued that continued current account deficits are unsustainable and increase the probability of a crisis. For example, the US is a debtor country and the current deficit/GDP has been increasing during the decade of the 1990s. Should this be construed as a sign of vulnerability. On the basis of our analysis based upon stochastic optimal control we answer the following questions: When optimal policies are followed, what is the expected current account? Can it be optimal that the richest country in the world be a debtor? What is a sustainable current account deficit? Our answer is summarized by proposition V. We explain the differences between our stochastic optimal control/dynamic programming approach $^{24}$ and that implied by the IBC literature. It is not always clear whether it is claimed that the observed market behavior is the optimal behavior described by the IBC literature or whether that concept of optimality is just a benchmark. Here, we take the weaker interpretation that the IBC provides a benchmark.

The main inter-related propositions implied by the IBC literature ${ }^{25}$ are as follows. (i) The expected present value of absorption - public plus private consumption plus investment - is equal to the expected present value of GDP. Trade deficits are means to smooth inter-temporal consumption, and they have expected present values of zero ${ }^{26}$. The expected present value of the foreign debt is zero. (ii) The optimal current account is equal to the difference between current national income and from its "permanent" level less the deviation of government consumption from its "permanent" level ${ }^{27}$. The "permanent" level of national income is the annuity value of the expected present value of national income. (iii)The stock of capital is such that the expected marginal product of capital is equal to the interest rate. 
Despite its great popularity in the theoretical literature, the IBC has not been used in empirical or policy oriented work to evaluate whether the current account deficit is sustainable or optimal. The reason for this disparity between "theory" and "empirical/policy" is that IBC literature is not operational. The Intertemporal Budget Constraint propositions (i) - (ii) above are unenforceable. No one can know with reasonable confidence what is the expected present value of future GDP. When current account deficits are incurred, no one can say with any confidence that they just reflect consumption smoothing and that they will be reversed in the future, so that there will not be a debt crisis. There is no objective measure of what is an unsustainable situation. There is no feedback control to correct errors. As more information is obtained about future real income, how should previous errors - excessive trade deficits - be corrected?

Moreover, there is a serious problem concerning investment and trade deficits, which finance the excess of investment over saving. Point (iii) above states that as long as the expected marginal product of capital exceeds the interest rate, the stock of capital should be increased. In our model, the expected marginal return on investment is constant $a t b>0$, there are no diminishing returns to investment. This implies that if $b$ exceeds the real interest rate $r$ an infinite amount of investment should be undertaken. Given the saving ratio, an infinite amount of debt should be incurred. Since both the return on investment and the interest rate are stochastic, this is an extremely risky policy that cannot be optimal.

The results in BOX 2/figures 1-2 show why the stochastic optimal control/dynamic programming approach arrives at propositions very different from the IBC propositions above. First: Even though the constant expected return on investment exceeds the constant expected real rate of interest, say $b-r=0 B$ in figure 1 , the optimal debt/net worth is finite at $\mathrm{f}^{*}(\mathrm{~B})$. The ratio of capital to net worth $\mathrm{k}^{*}=1+\mathrm{f}^{*}=1+\mathrm{f}^{*}(\mathrm{~B})$ is also finite.

Second: In our DP analysis, permanent current account deficits will be optimal if the optimal debt/net worth $\mathrm{f}^{*}$ and growth are positive. Then the debt 
should grow at the same rate as net worth. Since the current account deficit is the change in the debt, it is optimal to have continuing current account deficits. The derivation of the optimal current account deficit is as follows. Since the ratio $f^{*}=$ $\mathrm{L}(\mathrm{t}) / \mathrm{X}(\mathrm{t})$ is the ratio of optimal debt/net worth, the optimal current account deficit/net worth is ${ }^{28}$ (24a) $d L^{*}(\mathrm{t})=\mathrm{f}^{*} \mathrm{dX}(\mathrm{t})$ where $\mathrm{dL}^{*}(\mathrm{t})$ is the change in the debt. The optimal ratio $\mathrm{f}^{*}$ is a control variable in this model and is constant. The actual change in net worth $d X(t)$ in equation (10a) has two components: a mean $\mathrm{M}(\mathrm{f}, \mathrm{c})=[(\mathrm{b}-\mathrm{c})+(\mathrm{b}-\mathrm{r}) \mathrm{f}] \mathrm{X}(\mathrm{t})$ and a stochastic part containing the two Brownian motion terms with zero expectations. The actual change in net worth will jump around due to the Brownian motion terms. The expectation of the change in the debt/net worth is equation (24). Denote the expected current account deficit/net worth denoted by $Z(t)$,

(24) $\mathrm{Z}\left(\mathrm{f}^{*}, \mathrm{c}^{*}\right)=\mathrm{E}(\mathrm{dL}(\mathrm{t}) / \mathrm{X}(\mathrm{t}))$

$$
=\mathrm{f}^{*} \mathrm{E}[\mathrm{dX}(\mathrm{t})] / \mathrm{X}(\mathrm{t})=\mathrm{f}^{*}\left[\left(\mathrm{~b}-\mathrm{c}^{*}\right)+(\mathrm{b}-\mathrm{r}) \mathrm{f}^{*}\right]=\mathrm{f}^{*} \mathrm{M}\left(\mathrm{f}^{*}, \mathrm{c}^{*}\right) .
$$

The expected optimal current account deficit/net worth is a quadratic function of the optimal debt $\mathrm{f}^{*}$ ratio. The term $\mathrm{M}(\mathrm{f}, \mathrm{c})$ is what we called the "Mean" in the $\mathrm{M}-\mathrm{V}$ analysis, equation (19), or the straight line in figure 2 . The graph of equation (24) is a parabola. There are two roots. One is the origin $f_{1}=0$. The second is $f_{2}$ $=-(b-c) /(b-r)=-$ slope $M(f, c) /$ intercept $M(0, c)$. Figure 3 draws $Z(t)$ in the case corresponding to figure 2 , and where the utility function is logarithmic so that the consumption/GDP ratio is equal to the discount rate, $\mathrm{c}=\delta$, and independent of the debt. Since both slope and intercept of the $M(f, c)$ function in figure 2 are positive, root $f_{2}$ is negative. This implies that the $Z(f)$ is positive for positive deb. When the optimal debt $\mathrm{f}^{*}>0$, there will be permanent current account deficits/net worth. 


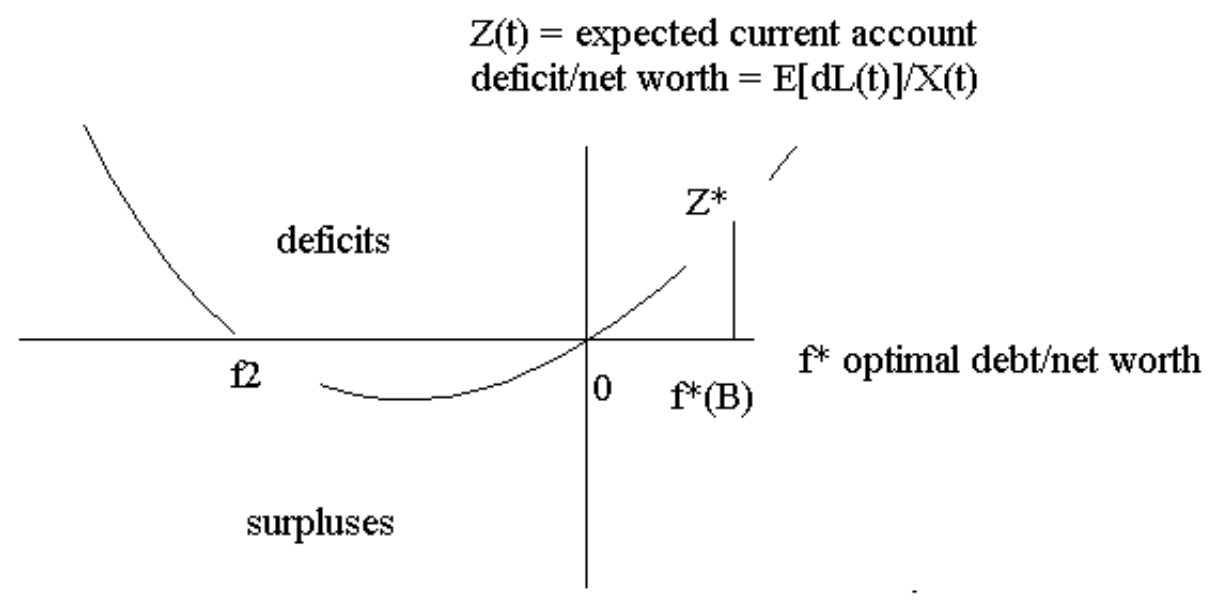

Figure 3. Optimal expected current account deficit/net worth

If the optimal debt/net worth were positive, such as point $\mathrm{f}^{*}(\mathrm{~B})$ in figure 1 , or $f^{*}$ in figure 2 , then the current account deficit/net worth is $Z^{*}=f^{*} M^{*}\left(f^{*}, \delta\right)$ in figure 3. By running these expected deficits, the ratio of the debt to the net worth 
is held constant. We have therefore proved PROPOSITION V: the expectation of permanent current account deficits may be optimal.

We may sum up the differences between the DP approach and the IBC literature concerning the optimal current account as follows. (a) The IBC is unknowable and cannot be enforced at any time. (b) In the DP approach, a permanent debtor or creditor position may be optimal. It all depends upon the mean net return on investment (b-r) relative to the magnitude of the risks on investment and the real long term rate of interest, their correlations and risk aversion, as shown in BOX 2. (c) In the IBC literature, the optimum current account at any time depends upon the difference between current and "permanent income". (d) In the DP approach, insofar as the optimal debt/net worth is a positive constant, such as point $0 \mathrm{~B}$ in figure 1, then permanent current account deficits are required to maintain the ratio constant. (e) The current account deficit/net worth should be stationary if the expected net return $(b-r)$ is stationary.

\section{Mathematical Derivation of Optimal Consumption, Capital, Debt in Continuous Time over an Infinite Horizon}

In this mathematical part, we use the dynamic programming method ${ }^{29}$ to solve equations (1) and (10) and derive equation (11) for the optimal debt and consumption over an infinite horizon. The economic interpretation of the results stated in propositions I-V is the subject of parts 3-7 above. The mathematical analysis proceeds in several steps.

Section 8.1. (a) Derive the Bellman stochastic dynamic programming (DP) equation. (b) Prove that the HARA utility function, equation (2), implies that the value function $\mathrm{V}(\mathrm{X})$ in equation (1) is homogeneous of degree $\gamma$. The HARA function permits us to measure the variables: consumption $\mathrm{C} / \mathrm{X}=\mathrm{c}$, capital $\mathrm{k}=$ $\mathrm{K} / \mathrm{X}$ and debt $\mathrm{L} / \mathrm{X}=\mathrm{f}$ as fractions of $\mathrm{X}$ net worth, where lower case letters refer to the ratios. Instead of $\mathrm{C}$ and $\mathrm{L}$, we can equivalently take $\mathrm{c}$ and $\mathrm{f}$ as the control 
variables. Section 8.2. Solve the DP equation (11) for the optimal controls, the ratio of consumption/net worth and debt/net worth. These are equations (12) and (14) in BOX 2. Section 8.3. (a) Derive the equation for the optimal growth rate, its expectation and variance. (b) Prove that the value of the debt/net worth that maximizes the expected growth rate is precisely the optimum debt/net worth that maximizes the value function, and is equation (12) in BOX 2. (c) The value of the debt/net worth that minimizes the variance of the growth rate is precisely the intercept term $\mathrm{f}(0)$ in the equation (12) for the optimum debt/net worth.

\subsection{The Dynamic Programming Equation ${ }^{30}$}

If $\mathrm{V}(\mathrm{X})$ is the value function as specified in (1), and the dynamic equation for $\mathrm{dX}(\mathrm{t})$ is given by (10) or (10a), the Dynamic Programming Principle implies equation (25). The admissible controls are $\mathrm{u}(\mathrm{t})=[\mathrm{C}(\mathrm{t})>0, \mathrm{~L}(\mathrm{t})]$ and $\mathrm{X}(\mathrm{t})>0$ is the state. Differential generator $G^{\mathrm{u}} \mathrm{V}(\mathrm{X})$ is defined in (25a). It involves the first two derivatives of function $\mathrm{V}(\mathrm{X})$. Candidates for the optimal control policy $\mathrm{u}^{*}(\mathrm{X})$ $=\left[C^{*}(X), L^{*}(X)\right]$ satisfy $(25 b)$. Equation $(10 a)$ can be rewritten as $(10 b)$ where: $\mathrm{F}(\mathrm{X}(\mathrm{t}), \mathrm{u}(\mathrm{t}))=\mathrm{bX}(\mathrm{t})+(\mathrm{b}-\mathrm{r}) \mathrm{L}(\mathrm{t})-\mathrm{C}(\mathrm{t})$, and $\Sigma$ and $\mathrm{dw}$ are vectors. The vector $\Sigma(\mathrm{X}(\mathrm{t}), \mathrm{u}(\mathrm{t}))=\left[\sigma_{2}(1+\mathrm{f}) \mathrm{X}(\mathrm{t}),-\sigma_{1} \mathrm{fX}(\mathrm{t})\right)$ and vector $\left.\mathrm{dw}(\mathrm{t})=\mathrm{dw}_{1}(\mathrm{t}), \mathrm{dw}_{2}(\mathrm{t})\right)$. (10b) $d X(t)=F(X(t), u(t)) d t+\Sigma(X(t), u(t)) d w(t)$.

(25) $\delta \mathrm{V}(\mathrm{X})=\max _{\mathrm{u}}\left[\mathrm{G}^{\mathrm{u}} \mathrm{V}(\mathrm{X})+(1 / \gamma) \mathrm{C}^{\gamma}\right]$

(25a) $\mathrm{G}^{\mathrm{u}} \mathrm{V}(\mathrm{X})=\mathrm{F}(\mathrm{X}, \mathrm{u}) \mathrm{V}_{\mathrm{x}}+(1 / 2) \Sigma \Sigma^{\prime} \mathrm{V}_{\mathrm{xx}}$. (25b) $\mathrm{u}^{*}(\mathrm{X}) \in \operatorname{argmax}_{\mathrm{u}}\left[\mathrm{G}^{\mathrm{u}} \mathrm{V}(\mathrm{X})+(1 / \gamma) \mathrm{C}^{\gamma}\right]$.

The HARA utility function implies that the value function $\mathrm{V}(\mathrm{X})$ in equation (1), and hence $\mathrm{V}(\mathrm{X})$ in (25), is homogeneous of degree $\gamma<1, \gamma \neq 0$. The proof is as follows ${ }^{31}$. If the state $\mathrm{X}$, and controls $\mathrm{C}$ and $\mathrm{L}$ are multiplied by a value $\lambda>0$, then the new value function $\mathrm{V}(\lambda \mathrm{X})$ is:

(26) $\mathrm{V}(\lambda \mathrm{X})=\max _{\Gamma} \mathrm{E}\left\{\int_{0}^{\infty}(1 / \gamma)[\lambda \mathrm{C}(\mathrm{t})]^{\gamma} \mathrm{e}^{-\delta \mathrm{t}} \mathrm{dt}\right\}=\lambda^{\gamma} \mathrm{V}(\mathrm{X})$ 
Therefore, the value function of $\mathrm{X}$ is also homogeneous of degree $\gamma$. One may write the value function as (27) where constant $\mathrm{A}>0$ is to be determined. The first two derivatives are (27b) and (27b).

(27) $\mathrm{V}(\mathrm{X})=(\mathrm{A} / \gamma) \mathrm{X}^{\gamma} ;(27 \mathrm{a}) \mathrm{V}_{\mathrm{x}}=\mathrm{A} \mathrm{X}^{(\gamma-1)} ;(27 \mathrm{~b}) \mathrm{V}_{\mathrm{xx}}=\mathrm{A}(\gamma-1) \mathrm{X}^{(\gamma-2)}$

From the equations above and dynamic equation (10a), the Bellman stochastic dynamic programming (DP) equation is (18) repeated here .

\section{DP equation, HARA case $\gamma<1, \gamma \neq 0$.}

(11) $\delta / \gamma=b+\max _{c}\left[(1 / \gamma) c^{\gamma} / A-c\right]+\max _{f}\left[(b-r) f+(\gamma-1) / 2\left(f^{2} \sigma_{1}{ }^{2}\right)\right.$ $\left.+(\gamma-1) / 2(1+\mathrm{f})^{2} \sigma_{2}^{2}-(\gamma-1)(1+\mathrm{f}) \mathrm{f} \rho \sigma_{1} \sigma_{2}\right]$

Ratios $\mathrm{c}=(\mathrm{C} / \mathrm{X})>0, \mathrm{f}=\mathrm{L} / \mathrm{X}>-1$ are the controls. On the basis of equation (25), we derive the optimal ratio of debt/net worth and consumption/net worth. The economic analysis in parts 3-7 above is based upon this equation.

\subsection{Optimal debt $\mathrm{f}^{*}$ and consumption $\mathrm{c}^{*}$ relative to net worth}

There are two parts in brackets in equation (11): a maximum with respect to debt/net worth $\mathrm{f}$ and to consumption/net worth $\mathrm{c}$. The maximum with respect to c occurs at:

(28) $\mathrm{c}^{*}=\mathrm{C}(\mathrm{t}) / \mathrm{X}(\mathrm{t})=\mathrm{c}^{*}=\mathrm{A}^{1 /(\gamma-1)}$

Where $\mathrm{A}>0$ is determined as shown in Fleming (2001) and Fleming and Stein (2002). When the utility function is logarithmic $\mathrm{U}(\mathrm{C}(\mathrm{t}))=\ln \mathrm{C}(\mathrm{t})$, which corresponds to $\gamma=0$, then the optimal consumption/net worth ratio $\mathrm{c}^{*}$ is equal to the discount rate $\delta>0$. This is equation (14) above, repeated here. (14) $\mathrm{c}^{*}=\delta>0$.

The maximization over $f \geq-1$ in (11) is derived from the second term. The constraint means that net worth $\mathrm{X}(\mathrm{t})>0$, to avoid Ponzi schemes. The maximum occurs at $\mathrm{f}^{*}$ in equation (12) above, repeated here.

(12) $\mathrm{f}^{*}=(\mathrm{b}-\mathrm{r}) /(1-\gamma) \sigma^{2}+\lambda(\rho \theta-1)=(\mathrm{b}-\mathrm{r}) /(1-\gamma) \sigma^{2}+\mathrm{f}(0)$. 
We have derived the optimal controls stated in BOX 2, whose economic interpretations were discussed above.

\subsection{The growth rate: expectation and variance}

The change in net worth is equation (10a) abbreviated here as (29). It describes the dynamics implied by the model, and there is no optimization involved. We show that the expected growth net worth is maximized when the optimal controls are used. This mathematics underlies the M-V presentation in part 4 above. In this section, ratios $f$ and $\mathrm{c}$ are assumed constant.

(29) $d X(t)=M X(t) d t+B_{1} X(t) d w_{1}+B_{2} X(t) d w_{2}$.

$$
M=[(b-c)+(b-r) f] ; B_{1}=-f \sigma_{1} ; B_{2}=(1+f) \sigma_{2} ; d w_{i}=\varepsilon_{i} \sqrt{ } d t \quad i=1,2, \varepsilon \sim N(0,1)
$$

In the deterministic case, the growth rate $(1 / \mathrm{X}) \mathrm{dX}(\mathrm{t}) / \mathrm{dt}$ is the term $\mathrm{M}(\mathrm{f}, \mathrm{c})$. It arises from the expected return on saving (b-c), plus the net expected return from borrowing (b-r)f. The stochastic elements add the second and third terms in (29). The dynamics of wealth equation (29) is an Ito process. Using the stochastic calculus ${ }^{32}$, it implies (30) for the $\ln \mathrm{X}(\mathrm{t})$, the logarithm of net worth ${ }^{33}$. This equation is tied directly to the $\mathrm{M}-\mathrm{V}$ analysis in figure 2, by using the definitions for $\mathrm{M}$ and $\mathrm{R}$ in equations (17) and (18) above.

(30) $\ln \mathrm{X}(\mathrm{t}) / \mathrm{X}(0)=\{\mathrm{M}(\mathrm{f}, \mathrm{c})-\mathrm{R}(\mathrm{f})\} \mathrm{t}+\left[\mathrm{B}_{1} \mathrm{w}_{1}(\mathrm{t})+\mathrm{B}_{2} \mathrm{w}_{2}(\mathrm{t})\right], \mathrm{w}(\mathrm{t})=\int \mathrm{dw}(\mathrm{t})$ The first term in braces in equation (30) is the expected growth rate, $\mathrm{g}(\mathrm{f}, \mathrm{c})$ in equation (31).

(31) $g(f, c)=(1 / t) E[\ln (X(t) / X(0))]=M(f, c)-R(f)$

The expected growth rate $g(f, c)=M(f, c)-R(f)$ is precisely the term that we maximized with respect to $\mathrm{f}=\mathrm{debt} / \mathrm{GDP}$ in DP equation (11) above, when $\gamma=$ 0 . It is the vertical difference between the mean $\mathrm{M}$ and risk $\mathrm{R}$ curves in figure 2. We have proved that: The optimal debt/net worth $f^{*}$ (or capital/net worth $k^{*}$ ) in equation (11) also maximizes the expected endogenous growth rate, for any 
constant consumption ratio. The optimal debt/GDP and "capital"/GDP are independent of the discount rate.

The variance of the growth rate, from equation (31) is equation (33).

(32) $(1 / \mathrm{t}) \operatorname{var} \ln \mathrm{X}(\mathrm{t}) / \mathrm{X}(0)=(1 / \mathrm{t}) \mathrm{E}\left[\mathrm{B}_{1} \mathrm{w}_{1}(\mathrm{t})+\mathrm{B}_{2} \mathrm{w}_{2}(\mathrm{t})\right]^{2}$

$$
=\left[\mathrm{f}^{2} \sigma_{1}^{2}+(1+\mathrm{f})^{2} \sigma_{2}^{2}-2 \mathrm{f}(1+\mathrm{f}) \rho \sigma_{1} \sigma_{2}\right]=2 \mathrm{R}(\mathrm{f})
$$

The variance depends upon $\mathrm{f}$ but not on $\mathrm{c}$. The variance of the growth rate is twice the risk $R(f)$ function graphed in figure 2. It is a convex function of the debt. The minimum value of the risk is obtained when $f=f(0)=\lambda(\rho \theta-1)$.

(33) $\mathrm{f}(0)=\operatorname{argmin}_{\mathrm{f}}\left[\mathrm{f}^{2} \sigma_{1}^{2}+(1+\mathrm{f})^{2} \sigma_{2}^{2}-2 \mathrm{f}(1+\mathrm{f}) \rho \sigma_{1} \sigma_{2}\right]$

The debt associated with the minimum value of the risk $f(0)$ is precisely the intercept term in the optimal debt/net worth in equation (12), and the M-V graph in figure 2 .

\section{Conclusion}

We use stochastic optimal control-dynamic programming (DP) to derive the optimal foreign debt/net worth, consumption/net worth, current account/net worth, and endogenous growth rate in an open economy. Unlike the literature that uses an Intertemporal Budget Constraint (IBC) or the Maximum Principle, the DP approach is operational. It does not require perfect foresight or certainty equivalence. Errors of measurement and the effects of unanticipated shocks are corrected in an optimal manner. We contrast the DP and IBC approaches, show how the results of the dynamic programming approach can be interpreted in a traditional simple mean-variance/Tobin-Markowitz context, and explain why our results are generalizations of the Merton model. 


\section{REFERENCES}

Easterly, William and Ross Levine (2001) It's Not Factor Accumulation: Stylized Facts and Growth Models, World Bank Economic Review, Working Paper

Friedman, Milton and Anna Schwartz (1963) A Monetary History of the United States, Princeton University Press

Fleming, Wendell H. and Jerome L. Stein (2001), Stochastic Inter-temporal Optimization in Discrete Time, in Negishi,Takashi, Rama Ramachandran and Kazuo Mino (ed) Economic Theory, Dynamics and Markets: Essays in Honor of Ryuzo Sato, Kluwer.

(2002) Optimal Investment-Consumption Models in International Finance, Division of Applied Mathematics, Brown University Working Paper

Fleming, Wendell H. (2001) Stochastic Control Models of Optimal Investment and Consumption, Aportaciones Mathemáticas, Modelos Estocásticos II, in D. Hernández, J. A. López-Mimbela, R. Quezada, Sociedad Mathemátics, Mexico (1999), Controlled Markov Processes and Mathematical Finance, in F. H. Clarke and R. J. Stern (ed.) Nonlinear Analysis, Differential Equations and Control, Kluwer,

and H. M. Soner, (1992), Controlled Markov Processes and Viscosity Solutions, New York: Springer Verlag

-------------and Raymond Rishel, (1975)Deterministic and Stochastic Optimal Control, Springer-Verlag.

Gandolfo, Giancarlo (2001) International Finance and Open-Economy Macroeconomics, Springer

Hahn, F. and R.M.Solow (1995) A Critical Essay on Modern Macroeconomic Theory, Blackwell.

Infante, Ettore and Jerome L. Stein (1973) Optimal Growth with Robust feedback Control, Review of Economic Studies XL, 47-60

International Monetary Fund, World Economic Outlook (WEO), Crisis in Asia, Interim Assessment, December 1997, Washington, DC 
----------------------World Economic Outlook (WEO), Financial Crises, May

1998, Washington, DC

Merton, Robert K. Continuous Time Finance, Blackwell, 1990

Obstfeld, M. and K. Rogoff (1996) Foundations of International Macroeconomics, MIT press

Samuelson, Paul, Lifetime Portfolio Selection by Dynamic Stochastic Programming, Collected Papers III, MIT Press, 1972

Stein, Jerome L. and Giovanna Paladino (2001) Country Default Risk: An Empirical Assessment, Australian Economic Papers, 40, 4, December .

Turnovsky, S. (2000) Methods of Macroeconomic Dynamics, MIT Press

World Bank/International Monetary Fund/World Trade Organization, Conference on Capital Flows, April 1999, World Bank, Washington, DC 
${ }^{1}$ See Monetary Fund, International Capital Markets, Washington DC (1999), and International
Monetary Fund, Anticipating Balance of Payments Crises, Occasional Paper \#186, (1999).
${ }^{2}$ The market expectations as embodied in interest rates did not widen significantly prior to the Mexican crisis. In the Asian crises, spreads hardly increased in the months prior to the floatation of the Bhat. The credit rating agencies and the market analysts all failed to signal the Asian crises in advance. They downgraded these countries only after the crises.

${ }^{3}$ See Gandolfo (2001, ch.1,18), Hahn and Solow (1995), Infante and Stein (1973) and Stein and Paladino (1997).

${ }^{4}$ James Tobin (1918 - 2002) developed the content of his "Liquidity Preference" RES 1958 paper in 1950, in his graduate course on macroeconomics where Stein was a graduate student. It is fitting that this paper be dedicated to this "gentleman and scholar".

${ }^{5}$ Equation (4) is a generalization of the AK production function.

${ }^{6}$ There is no need for us to discuss here the extensive literature that attempts to explain the "Solow residual" or the "something else".

${ }^{7}$ The production function is $\ln [\mathrm{Y}(\mathrm{t}) / \mathrm{Y}(0)]=\int\left[\mathrm{bI}(\mathrm{s}) / \mathrm{Y}(\mathrm{s})-\sigma^{2}{ }_{2} / 2\right] \mathrm{ds}+\sigma \mathrm{w}(\mathrm{t})$, $\mathrm{w}(\mathrm{t})=\int \mathrm{dw}(\mathrm{s}), 0<\mathrm{s}<\mathrm{t}$

${ }^{8}$ The analysis in the Fleming-Stein (2001) paper was applied by Stein and Paladino (2001) to explain which countries have renegotiated their debts.

${ }^{9}$ See Friedman and Schwartz (1963, p. 312). The negative correlation between growth and the yield on lower grade bonds is crucial in understanding the severity of the depression and financial crises.

${ }^{10}$ See the mathematical section below.

${ }^{11}$ In the models that use IBC, one must know the expected present value of future income over (say) an infinite horizon. In the model in BOX 1, such a concept is unknowable.

${ }^{12}$ The converse is not true, except in the case of the logarithmic utility function.

${ }^{13}$ From 1973:1 - 2000:1, the mean return on investment $b=14.8 \%$ pa and the mean real long term interest rate $\mathrm{r}=3.8 \%$ pa.

${ }^{14}$ The sample period is 1973:1 - 2000:1.

${ }^{15}$ Ratio $\theta=\sigma_{1} / \sigma_{2}=0.18$ is standard deviation of interest rate/ standard deviation of growth .

${ }^{16}$ This issue is discussed in detail in Infante and Stein (1973), where a dynamic programming approach is taken. See also Gandolfo (2001, pp. 306-07).

${ }_{18}^{17}$ Markowitz provided an algorithm to derive the efficient frontier.

${ }^{18}$ The mathematical analysis is in part 8 .

${ }^{19}$ If the utility function is logarithmic $(\gamma=0)$, then the ratio $\mathrm{c}$ of consumption/net worth is a constant equal to the discount rate $\delta>0$. The growth of utility, the growth of consumption and the growth of net worth, over time interval $[0, t]$, the present time $t=0$, are equal and are described by equation (15a).

$(15 \mathrm{a})[\mathrm{U}(\mathrm{t})-\mathrm{U}(0) / \mathrm{t}=(1 / \mathrm{t}) \ln [\mathrm{C}(\mathrm{t}) / \mathrm{C}(0)]=(1 / \mathrm{t}) \ln [\mathrm{X}(\mathrm{t}) / \mathrm{X}(0)]$, when the utility function is logarithmic.

${ }^{20}$ The net debt is constrained to exceed -1 , because $\mathrm{f}=\mathrm{k}-1$, and capital/net worth $\mathrm{k}$ is nonnegative. At $\mathrm{f}=-1$, the country has no capital, and all of its assets are foreign obligations.

${ }^{21}$ Let a country borrow to finance investment. The total risk concerns the difference between the gross return on investment $\mathrm{dY}(\mathrm{t}) / \mathrm{Y}(\mathrm{t})$ and the rate of interest $\mathrm{r}(\mathrm{t})$. The variance of this net return $\operatorname{var}(\mathrm{dY} / \mathrm{Y}(\mathrm{t})-\mathrm{r}(\mathrm{t}))$ is total risk $\sigma^{2}$, equation (a) $\sigma^{2}=\sigma_{2}^{2}\left(1+\theta^{2}-2 \rho \theta\right), \theta=\sigma_{1} / \sigma_{2}$. Term $\lambda=1 /(1+$ $\left.\theta^{2}-2 \rho \theta\right)=\sigma_{2}{ }^{2} / \sigma^{2}$ is the ratio of the risk on the return $\sigma_{2}^{2}$ /total risk $\sigma^{2}$. It is greater (less) than 1 if risky borrowing reduces (increases) total risk. The debt is negative if the country is a creditor. The slope of the quadratic risk function evaluated at $f=0$ is $R_{f}(0)=\sigma_{2}^{2}(1-\rho \theta)$, where $\theta=\sigma_{1} / \sigma_{2}$ is the ratio of the interest rate risk to the risk of the productivity of investment, and $\rho$ is the correlation between the return and the interest rate. The change in $\mathrm{V}^{*}$, the $\mathrm{M}-\mathrm{V}$ expected utility at $\mathrm{f}$ 
$=0$, is $d V^{*}(0, c) / d f=(b-r)-\sigma_{2}^{2}(1-\rho \theta)$. Figure 2 is drawn for the case where $d V^{*}(0, c) / d f>0$, it is optimal to be a debtor

${ }^{21}$ The net debt is constrained to exceed -1 , because $\mathrm{f}=\mathrm{k}-1$, and capital/net worth $\mathrm{k}$ is nonnegative. At $\mathrm{f}=-1$, the country has no capital, and all of its assets are foreign obligations.

${ }^{22}$ We use our notation, for purposes of comparison.

${ }^{23}$ The discount rate, in effect, reflects inversely the length of the horizon.

${ }^{24}$ Stein and Paladino (2001) evaluate the "sustainablility/solvency" criteria concerning a short term external debt. Then, they apply work by Fleming and Stein (2001) to provide an objective implementable estimate of country default risk.

${ }^{25}$ The IBC is discussed fully in Gandolfo (2001:ch.18-19), Obstfeld \& Rogoff (1996; pp. 60- 87).

${ }^{26}$ Let the initial debt be zero.

${ }^{27}$ See Gandofo: 305.

${ }^{28}$ The optimal debt $L^{*}(t)=f^{*} X(t)=L(X(t))$, where $L_{x}=f^{*}$ and $L_{x x}=0$. Therefore the change $d L(t)$ $=\mathrm{L}_{\mathrm{x}} \mathrm{dX}(\mathrm{t})+\left(\mathrm{L}_{\mathrm{xx}} / 2\right)(\mathrm{dX}(\mathrm{t})) 2=\mathrm{f}^{*} \mathrm{dX}(\mathrm{t})$.

${ }^{29}$ The dynamic programming method is presented in a form accessible to economists in Turnovsky ch. 15. Mathematical analyses of the Dynamic Programming method in finance models is in Fleming (1999), (2001) and Fleming and Soner (1992).

${ }^{30}$ See Fleming (2001) and Fleming and Stein (2002) for more technical details.

${ }^{31}$ The logarithmic case, corresponding to $\gamma=0$, implies $\mathrm{V}(\mathrm{X})=\mathrm{A} \ln \mathrm{X}+\mathrm{B}$, where $\mathrm{A}$ and $\mathrm{B}$ are to be determined.

${ }^{32}$ Integrate $d(\ln X(t))=(1 / X(t)) d X(t)-\left(1 / 2 X^{2}(t)\right)(d X(t))^{2}$.

${ }^{33}$ Insofar as the initial net worth $X(0)>0$, the net worth $X(t)$ at any time $t$ will be positive, because each exponential is non-negative.

$$
\mathrm{X}(\mathrm{t})=\mathrm{X}(0)[\exp (\mathrm{g}(\mathrm{f}, \mathrm{c}) \mathrm{t})]\left\{\exp \left[\mathrm{B}_{1} \mathrm{w}_{1}(\mathrm{t})+\mathrm{B}_{2} \mathrm{w}_{2}(\mathrm{t})\right]\right\}>0, \text { for } \mathrm{X}(0)>0 .
$$




\section{CESifo Working Paper Series}

677 Kai Sülzle and Achim Wambach, Insurance in a Market for Credence Goods, February 2002

678 Paul de Bijl and Martin Peitz, New Competition in Telecommunications Markets: Regulatory Pricing Principles, March 2002

679 Tilman Börgers and Christian Dustmann, Rationalizing the UMTS Spectrum Bids: the Case of the UK Auction, March 2002

680 Christian Ewerhart and Benny Moldovanu, The German UMTS Design: Insights From Multi-Object Auction Theory, March 2002

681 Gebhard Flaig, Unobserved Components Models for Quarterly German GDP, March 2002

682 Steffen H. Hoernig and Tommaso M. Valletti, The Interplay Between Regulation and Competitions: The Case of Universal Service Obligations, March 2002

683 Jörg Baten, Did Partial Globalization Increase Inequality? Did Inequality Stimulate Globalization Backlash? The case of the Latin American Periphery, 1950-80, March 2002

684 Norman Loayza and Romain Ranciere, Financial Development, Financial Fragility, and Growth, March 2002

685 Thomas Eichner and Andreas Wagener, Increases in Risk and the Welfare State, March 2002

686 Hyun Park and Apostolis Philippopoulos, Can Poductive Government Spending be the Engine of Long-Run Growth When Labor Supply is Engogenous?, March 2002

687 Jonathan P. Thomas and Tim Worrall, Gift-Giving, Quasi-Credit and Reciprocity, March 2002

688 Barbara Buchner, Carlo Carraro, Igor Cersosimo, and Carmen Marchiori, Back to Kyoto? US Participation and the Linkage between R\&D and Climate Cooperation, March 2002

689 Amihai Glazer and Vesa Kanniainen, The Effects of Employment Protection on the Choice of Risky Projects, March 2002

690 Michael Funke and Annekatrin Niebuhr, Threshold Effects and Regional Economic Growth - Evidence from West Germany, March 2002

691 George Economides, Apostolis Philippopoulos, and Simon Price, Elections, Fiscal Policy and Growth: Revisiting the Mechanism, March 2002 
692 Amihai Glazer, Vesa Kanniainen, and Mikko Mustonen, Innovation of Network Goods: A Non-Innovating Firm Will Gain, March 2002

693 Helmuth Cremer, Jean-Marie Lozachmeur, and Pierre Pestieau, Social Security, Retirement Age and Optimal Income Taxation, April 2002

694 Rafael Lalive and Josef Zweimüller, Benefit Entitlement and the Labor Market: Evidence from a Large-Scale Policy Change, April 2002

695 Hans Gersbach, Financial Intermediation and the Creation of Macroeconomic Risks, April 2002

696 James M. Malcomson, James W. Maw, and Barry McCormick, General Training by Firms, Apprentice Contracts, and Public Policy, April 2002

697 Simon Gächter and Arno Riedl, Moral Property Rights in Bargaining, April 2002

698 Kai A. Konrad, Investment in the Absence of Property Rights: The Role of Incumbency Advantages, April 2002

699 Campbell Leith and Jim Malley, Estimated General Equilibrium Models for the Evaluation of Monetary Policy in the US and Europe, April 2002

700 Yin-Wong Cheung and Jude Yuen, Effects of U.S. Inflation on Hong Kong and Singapore, April 2002

701 Henry Tulkens, On Cooperation in Musgravian Models of Externalities within a Federation, April 2002

702 Ralph Chami and Gregory D. Hess, For Better or For Worse? State-Level Marital Formation and Risk Sharing, April 2002

703 Fredrik Andersson and Kai A. Konrad, Human Capital Investment and Globalization in Extortionary States, April 2002

704 Antonis Adam and Thomas Moutos, The Political Economy of EU Enlargement: Or, Why Japan is not a Candidate Country?, April 2002

705 Daniel Gros and Carsten Hefeker, Common Monetary Policy with Asymmetric Shocks, April 2002

706 Dirk Kiesewetter and Rainer Niemann, Neutral and Equitable Taxation of Pensions as Capital Income, April 2002

707 Robert S. Chirinko, Corporate Taxation, Capital Formation, and the Substitution Elasticity between Labor and Capital, April 2002

708 Frode Meland and Gaute Torsvik, Structural Adjustment and Endogenous Worker Recall Probabilities, April 2002 
709 Rainer Niemann and Caren Sureth, Taxation under Uncertainty - Problems of Dynamic Programming and Contingent Claims Analysis in Real Option Theory, April 2002

710 Thomas Moutos and William Scarth, Technical Change and Unemployment: Policy Responses and Distributional Considerations, April 2002

711 Günther Rehme, (Re-)Distribution of Personal Incomes, Education and Economic Performance Across Countries, April 2002

712 Thorvaldur Gylfason and Gylfi Zoega, Inequality and Economic Growth: Do Natural Resources Matter?, April 2002

713 Wolfgang Leininger, Contests over Public Goods: Evolutionary Stability and the FreeRider Problem, April 2002

714 Ernst Fehr and Armin Falk, Psychological Foundations of Incentives, April 2002

715 Giorgio Brunello, Maria Laura Parisi, and Daniela Sonedda, Labor Taxes and Wages: Evidence from Italy, May 2002

716 Marta Aloi and Huw Dixon, Entry Dynamics, Capacity Utilisation and Productivity in a Dynamic Open Economy, May 2002

717 Paolo M. Panteghini, Asymmetric Taxation under Incremental and Sequential Investment, May 2002

718 Ben J. Heijdra, Christian Keuschnigg, and Wilhelm Kohler, Eastern Enlargement of the EU: Jobs, Investment and Welfare in Present Member Countries, May 2002

719 Tapio Palokangas, The Political Economy of Collective Bargaining, May 2002

720 Gilles Saint-Paul, Some Evolutionary Foundations for Price Level Rigidity, May 2002

721 Giorgio Brunello and Daniela Sonedda, Labor Tax Progressivity, Wage Determination, and the Relative Wage Effect, May 2002

722 Eric van Damme, The Dutch UMTS-Auction, May 2002

723 Paolo M. Panteghini, Endogenous Timing and the Taxation of Discrete Investment Choices, May 2002

724 Achim Wambach, Collusion in Beauty Contests, May 2002

725 Dominique Demougin and Claude Fluet, Preponderance of Evidence, May 2002

726 Gilles Saint-Paul, Growth Effects of Non Proprietary Innovation, May 2002

727 Subir Bose, Gerhard O. Orosel, and Lise Vesterlund, Optimal Pricing and Endogenous Herding, May 2002 
728 Erik Leertouwer and Jakob de Haan, How to Use Indicators for 'Corporatism' in Empirical Applications, May 2002

729 Matthias Wrede, Small States, Large Unitary States and Federations, May 2002

730 Christian Schultz, Transparency and Tacit Collusion in a Differentiated Market, May 2002

731 Volker Grossmann, Income Inequality, Voting Over the Size of Public Consumption, and Growth, May 2002

$732 \mathrm{Yu}-\mathrm{Fu}$ Chen and Michael Funke, Working Time and Employment under Uncertainty, May 2002

733 Kjell Erik Lommerud, Odd Rune Straume, and Lars Sørgard, Downstream Merger with Oligopolistic Input Suppliers, May 2002

734 Saku Aura, Does the Balance of Power Within a Family Matter? The Case of the Retirement Equity Act, May 2002

735 Sandro Brusco and Fausto Panunzi, Reallocation of Corporate Resources and Managerial Incentives in Internal Capital Markets, May 2002

736 Stefan Napel and Mika Widgrén, Strategic Power Revisited, May 2002

737 Martin W. Cripps, Godfrey Keller, and Sven Rady, Strategic Experimentation: The Case of Poisson Bandits, May 2002

738 Pierre André Chiappori and Bernard Salanié, Testing Contract Theory: A Survey of Some Recent Work, June 2002

739 Robert J. Gary-Bobo and Sophie Larribeau, A Structural Econometric Model of Price Discrimination in the Mortgage Lending Industry, June 2002

740 Laurent Linnemer, When Backward Integration by a Dominant Firm Improves Welfare, June 2002

741 Gebhard Kirchgässner and Friedrich Schneider, On the Political Economy of Environmental Policy, June 2002

742 Christian Keuschnigg and Soren Bo Nielsen, Start-ups, Venture Capitalits, and the Capital Gains Tax, June 2002

743 Robert Fenge, Silke Uebelmesser, and Martin Werding, Second-best Properties of Implicit Social Security Taxes: Theory and Evidence, June 2002

744 Wendell Fleming and Jerome Stein, Stochastic Optimal Control, International Finance and Debt, June 2002 